Marta Kaźmierczak (DD

Uniwersytet Warszawski

mkazmierczak@uw.edu.pl

\title{
Obraz Francji w wybranych rosyjskich przekładach A Sentimental Journey Sterne'a
}

\section{Wprowadzenie}

Artykuł podejmuje wątki związane $\mathrm{z}$ historią i ewolucją praktyk przekładowych: ma na celu zarysowanie tendencji w językowym i konceptualnym prezentowaniu obrazu Francji w rosyjskich przekładach Podróży sentymentalnej Laurence'a Sterne'a powstałych w XIX i XX wieku. Bohater i narrator powieści będącej zarazem esencją i parodią literatury sentymentalnej, pastor Yorick, pod wpływem impulsu wyrusza w podróż po Francji (i Italii) ${ }^{1}$ w poszukiwaniu wrażeń uczuciowych. Choć skupiony na przeżyciu, a nie na opisie turystycznych atrakcji, utwór uznawany jest za jeden z klasycznych opisów doświadczeń Anglika za granicą [Goring 2001: xi]. Przy tłumaczeniu A Sentimental Journey na każdy język poza francuskim mamy zatem do czynienia z kulturą trzecią jako istotnym składnikiem sytuacji komunikacyjnej.

\footnotetext{
1 Sterne zmarł w trakcie pracy nad tym utworem i włoska część wojażu Yoricka nie została opisana.
} 
W niniejszej pracy będę się posługiwać terminem ,elementy trzeciej kultury”, którego rozumienie przyjmuję za Dorotą Urbanek: to „te elementy tekstu oryginału i/lub przekładu, które są obce zarówno w języku i kulturze oryginału, jak i w języku i kulturze przekładu" [2002: 63]. Przejawiać się to może na różne sposoby. Szczególnie wyrazistym jest obecność w tekście obcojęzycznych wstawek (heterojęzyczność) - podsumowanie poglądów na ten temat oraz systematykę wtrętów obcojęzycznych w przekładzie zawiera moja wcześniejsza praca [Kaźmierczak 2016]. Do innych zauważanych przez badaczy ,trzeciokulturowych” nośników obcości należą nazwy realiów [por. Urbanek 2002: 65-68; Bednarczyk 2002] oraz nazwy własne [por. Wołek 2006]. Jednak obecność trzeciej kultury nie sprowadza się do wymiaru językowego: Anna Bednarczyk słusznie zauważa, że tłumacz jest - czy przynajmniej powinien być - w takiej sytuacji łącznikiem interkulturowym szczególnego rodzaju [2002: 49]. Jak podkreśla Elżbieta Skibińska [2008: 244], pojawienie się w tekście elementów trzeciej kultury zmienia układ translatoryczny, modyfikuje sytuację nadawczo-odbiorczą, m.in. w tym sensie, że autor czy podmiot występuje jako znawca przedstawiający obcy kontekst swojej publiczności. Sytuacja ta wymaga także szczególnej uwagi tłumacza i zastanowienia nad odczytaniami, do jakich będzie zachęcał przekład [ibidem: 263]. Wydaje mi się przy tym istotne zestawienie przekładów dawniejszych z nowszymi, by zbadać, jak na tłumaczenie elementów trzeciej kultury wpływają zmieniające się okoliczności historyczne i zmiany cywilizacyjne.

Wobec takiego celu narzuca się wybór jako materiału badawczego tekstów powstałych na tyle dawno, by mieć dość długą historię przekładową, a zarazem na tyle żywych, że ich recepcja nie zakończyła się w epoce współczesnej ich autorom. A Sentimental Journey Laurence'a Sterne'a spełnia to kryterium. Utwór powstał w roku 1768, a w kulturze rosyjskiej obecny jest - jako względnie kompletny tekst - od 1793 roku² do dziś. $\mathrm{Z}$ uwagi na dopuszczalną objętość publikacji ograniczę rozpatrywany materiał tylko do przekładów rosyjskich, i to zaledwie trzech, pomijając kilka innych. Za dokonaniem wyboru przemawiają ponadto takie czynniki jak słabość osiemnasto- i dziewiętnastowiecznych rosyjskich tłumaczeń [zob. Салиева 1992: 22-24], oparcie jednego z nich na języku-pośredni$\mathrm{ku}$ (francuskim, co czyni je nieprzydatnym dla zamierzonych tu badań),

Fragmenty ukazywały się po rosyjsku jeszcze wcześniej. 
a także ogólne podobieństwo strategii translatorskiej Adriana Frankowskiego i jego bezpośredniej poprzedniczki, Nadieżdy Wolpin (1935), które wskazał Piotr Budrin [Будрин 2016: 150-155]. Dlatego ograniczymy się do dwóch przekładów wczesnodziewiętnastowiecznych oraz najnowszego ogniwa. Są to:

Красоть Стерна - wyciąg z dzieł angielskiego autora, zawierający fragmenty Podróży sentymentalnej, który przełożył (z analogicznej antologii angielskiej) ${ }^{3}$ i wydał w Moskwie Jakow Andriejewicz Gali(e) nkowskij ${ }^{4}$ [Стерн 1801];

Путешествие Йорика по Франциии - anonimowe tłumaczenie w czterech częściach, wydrukowane w moskiewskiej drukarni uniwersyteckiej [Стерн 1806];

Сентиментальное путешествие по Франичи и Италии - wersja Adriana Frankowskiego z 1940 roku, uznawana za jedno ze znaczących osiągnięć radzieckiej szkoły przekładu [Стерн 1940/1968, online].

Pierwsze dwa wytypowane teksty dzieli bardzo niewiele czasu - co umożliwia porównanie synchroniczne; zostały też one wydane w tym samym ośrodku, choć nie do końca dla tego samego odbiorcy (o czym niżej). Zestawienie z nimi przekładu najpóźniejszego pozwoli natomiast uchwycić serię przekładową w perspektywie diachronicznej.

Mamy przy tym do czynienia z tekstami różnej objętości. Kpacombl Стерна, zgodnie z założeniem publikacji, zawierają obszerne fragmenty powieści; dwudziestowieczny przekład obejmuje całość utworu, natomiast moskiewskie wydanie z 1806 roku przynosi... więcej niż pełen tekst. Tłumaczenie to składa się z czterech tomów ${ }^{5}$, podczas gdy oryginał z dwóch. Wprawdzie na stronach tytułowych wszystkich części widnieje zapewnienie, że to ,,przekład z oryginału”, jednak z przedmowy do tomu III dowiadujemy się, że dwie ostatnie części nie wyszły spod pióra

3 Podstawa przekładu: The Beauties of Sterne; including all his pathetic tales, \& most distinguished observations on life. Selected for the heart of sensibility, London: printed for G. Kearsley, 1785, eighth edition, with considerable additions. Wybór i przedm.: W. H. (por. w przedmowie Galinkowskiego [Стерн 1801: III-IV]). W niniejszym studium przywołuję nieco późniejsze, ale wciąż osiemnastowieczne wznowienie [Beauties 1799].

4 Nazwisko bywa zapisywane dwojako: Galenkowskij lub Galinkowskij. Dedykację w Sternowskiej antologii tłumacz sygnował jako „Galinkowskij”, dlatego w niniejszym artykule przyjmuję takie brzmienie.

5 Taką objętość autor istotnie zamierzył, ale przed śmiercią zdążył napisać tylko połowę. 
Sterne'a - po jego śmierci dalszy ciąg podróży Yoricka miał spisać na podstawie ustnych opowieści autora jego przyjaciel, wspominany w powieści Eugenius (ros. Jewgienij) ${ }^{6}$. Ta część tekstu nie będzie nas interesować. Natomiast dobór przykładów częściowo podyktowany jest zawartością Sternowskiego kompendium z 1801 roku: skupię się na fragmentach obecnych nie tylko w pełnych wydaniach, ale także w tym wyborze.

Zaznaczmy, że dany materiał nie był, jak się wydaje, analizowany z takiej perspektywy. Rosyjscy badacze zajmowali się raczej kwestiami odtworzenia w przekładach osobliwości stylistyczno-narracyjnych (Ludmiła Salijewa, na podstawie pierwszego rozdziału powieści) oraz tłumaczeniami dwudziestowiecznymi, ich recepcją, manipulacjami paratekstowymi (Piotr Budrin) [zob. Салиева 1992; Будрин 2016]. Wariant Galinkowskiego chyba w ogóle nie przyciągał uwagi przekładoznawców.

Poniższą analizę staram się ująć możliwie syntetycznie. Dlatego jeśli omawiam jakieś zjawisko na materiale tylko jednego z tekstów, należy rozumieć, że w pozostałych ma miejsce zachowanie translatorskie zgodne z oczekiwaniami (transfer elementów heterojęzycznych czy przekład odzwierciedlający sformułowania oryginału), jeśli zaś na podstawie dwóch - znaczy to, że w wydaniu antologijnym dany fragment nie występuje.

\section{Obecność francuszczyzny w tkance tekstu}

Zacznijmy od licznych w tekście oryginału wtrętów w języku francuskim. Dwa przekłady z początku wieku XIX zasadniczo różnią się pod względem traktowania takich elementów. Galinkowskij zachowuje wiele $\mathrm{z}$ nich. W rozdziale Перчатки (tj. 'Rękawiczki', por. The Gloves [Sterne 20017: 52]) stosuje również przypis, w którym objaśnia, że wszystkie słowa francuskie odpowiadają takimże w tekście oryginalnym (,Bce французские слова, употребленные здесь, поставлены в тех же

6 A Sentimental Journey Continued, 1769. Autorstwo przypisywane jest tradycyjnie Johnowi Hallowi-Stevensonowi (1718-1785), przyjacielowi Sterne'a i pierwowzorowi „Eugeniusa”, jednakże współcześnie atrybucję tę się kwestionuje [por. m.in. Drabble 2000: s.v. Hall-Stevenson].

7 Posługuję się współczesnym wydaniem oryginału, jednak takim, w którym decyzje edytorskie nastawione są na zachowanie swoistości zapisu i interpunkcji Sterne'a [por. Goring 2001: xxxvi (Note on the text)]. W cytatach w niniejszej pracy również respektuję zapisy autora i jego thumaczy. 
местах, как и в подлиннике"” [Стерн 1801: 162]). Co ciekawe, przypis ten pojawia się dopiero na stronie 162, zapewne dlatego, że tam po raz pierwszy w wyborze (nierespektującym chronologii rozdziałów w powieściach, z których zaczerpnięto wyjątki) wtręty obcojęzyczne występują w znacznym zagęszczeniu. Wcześniej np. rozdział Le Patisser. Versailles [Sterne 2001: 76] otrzymuje rodzimy tytuł Пирожник. Версалия [1801: 116], gdzie naturalizacja ma sankcję normy w odniesieniu do egzonimu (por. niżej), lecz nie - rzeczownika pospolitego. Tytułowym sprzedawcą pasztecików (czy też ciastek, bo do takiego odczytania skłaniają się rosyjscy thumacze) okazuje się w nim „Chevalier de St. Louis (кавалер Св. Людовика)" - w takim, podwójnym zapisie - sprzedaje on jednak ,пирожки” [1801: 116], gdy u Sterne'a - patès [2001: 76, 77, tu i dalej słowa francuskie w pisowni autora]. Remise, którą jedzie podróżnik, staje się po prostu kolasą („коляска", [1801: 117]). Jedyny pozostały galicyzm wyjaśniony zostaje w osobnym (choć nie do końca precyzyjnym) przypisie:

У меня есть жена, которую я люблю и которая делает patisserie*.

* Пирожное [Стерн 1801: 120, sic].

Tym niemniej Galinkowskij nie odżegnuje się od wtrętów francuskich, choć występują one rzadziej niż w powieści Sterne'a. Mniejsza frekwencja w niewielkim stopniu thumaczy się zabiegami angielskiego antologisty - w Beauties odpowiedni rozdziałek [1799: 40-43] nosi wprawdzie angielski tytuł The Pie-Man, jednak pojawiają się w nim, wyróżnione kursywą, elementy francuskie: Chevalier de St. Louis, Versailles, pâtè, remise, pâtisserie, propreté, croix; Galinkowskij zachował spośród nich tylko zacytowane wyżej dwa.

\footnotetext{
8 W cytatach z przekładów dziewiętnastowiecznych pisownia została uwspółcześniona. W kontekście obecności w tekstach elementów obcojęzycznych istotna jest także - choć nie omawiam jej tu szerzej - kwestia wyróżnień typograficznych. Z tego względu zmuszona byłam odstąpić od zaleceń typograficznych pisma: w przytoczeniach kursywa odpowiada elementom objętym kursywą w tekstach, z których pochodzą dane wyjątki.

9 Acz w rozdziale Воскресенье (oryg. Le Dimanche) Galinkowskij sięgnie w tym wypadku po dublet translatorski: „нанять карету (remise)” [1801: 143]. Jak zwraca uwagę Percy Adams [2014: 213-223], powóz lub dyliżans to bardzo ważny motyw literatury podróżniczej tamtych czasów. Adams wskazuje [ibidem: 218] funkcję remise w rozwoju toku opowieści Sterne'a.
} 
Natomiast w przekładzie anonimowym wtręty są praktycznie nieobecne, zostają zastąpione ekwiwalentami rosyjskimi: nawet wykrzyknik Mon Dieu [Sterne 2001: 15, 21, 83] przekształca się w rodzime „Клянусь Богом”, „Клянусь Творцом”, „Боже мой” [Стерн 1806, vol. $1^{10}: 26,39$; vol. 2: 49]. Ciekawe, że wyrazy i zwroty odpowiadające elementom trzeciego języka są z reguły wyróżniane kursywą, np. сахарные пирожки [Стерн 1806, vol. 2: 33 i n.] na miejscu patès, patisserie (sic - w pisowni Sterne'a). Jednak zabieg ten nie może zostać właściwie odczytany bez porównania z tekstem oryginału: po pierwsze, czytelnik nie otrzymuje żadnego sygnału w paratekście, po drugie, pochyły druk obejmuje również inne elementy tekstu, np. cytowane - to samo wyróżnienie typograficzne pełni więcej niż jedną funkcję. Kursywa wydaje się tu mechanicznym odwzorowaniem typografii oryginału, pomimo że w procesie przekładu dokonała się zmiana statusu objętych nią odcinków tekstu.

Dwudziestowieczny przekład Adriana Frankowskiego zachowuje wtręty w przeważającej większości, od pojedynczych wyrażeń (,fille de chambre"), przez zdania (,c'est un cheval le plus opiniatre du monde"), po przytoczony w całości po francusku list [Стерн 1940/1968: online]. Będzie to również widoczne w przykładach cytowanych dalej.

Chciałabym natomiast zatrzymać się jeszcze przy sytuacjach, w których strategia autora anonimowej wersji z 1806 roku okazuje się problematyczna, mianowicie tam, gdzie użycie francuszczyzny ma charakter metajęzykowy. Tak jest we fragmencie komentującym kluczową rolę zwrotów tant pis i tant mieux w dyskursie Francuzów, konsekwentnie zastępowanych rosyjskimi odpowiednikami o analogicznym znaczeniu: 'tym gorzej' i 'tym lepiej'. Ma to miejsce, mimo że przedstawiona jest sytuacja poprawiania cudzoziemca oraz wyrażona zostaje rekomendacja opanowania tych zwrotów przed przybyciem do Paryża [Sterne 2001: 30] - z pewnością zatem chodzi o wyrażenia francuskie. Porównajmy:

and the landlord supposing I was young in French, took the liberty to inform me, I should not have said tant pis—but, tant mieux [Sterne 2001: 30]

и он сочтя, что я худо разумею по-французски, выдумал поучить меня. Вам должно бы сказать, сударь: не тем хуже, а тем лучше [Стерн 1806 vol. 1: 62].

10 Każda część posiada osobną numerację stron, stąd konieczność uwzględnienia numeru tomu w zapisie. 
W tym kontekście warto przypomnieć poczynioną przez Elżbietę Skibińską uwagę o istotności elementu prawdopodobieństwa - Skibińska pisze o motywacji psychologicznej [2012: 354], tu zaś chodzi o trafność sytuacyjną - wyboru języka i przełączania kodów w sytuacji heterojęzyczności w literaturze i przekładzie.

Francuszczyzna spełnia w utworze Sterne'a kilka funkcji - jedną z nich jest właśnie budowanie efektu prawdopodobieństwa; jak podobne zastosowanie określa Dorota Urbanek, stanowią one „naturalną część dyskursu" [2002: 63] - to naturalne, że Francuzi mówią i piszą po francusku i że podróżnik porozumiewa się z nimi w tym języku. Niekiedy jednak pisarz wydobywa aspekt metajęzykowy, a nawet metakulturowy. $\mathrm{W}$ ostatnim rozdziale części I Yorick komentuje różnice w pojmowaniu tego, co wypada, w różnych kulturach i przytacza anegdotę o Madame de Rambouliet, damie ze wszech miar przyzwoitej, która nie krępowała się objaśnić mu, czego sobie życzy, zatrzymując karetę:

I asked her if she wanted any thing-Rien que pisser, said Madame de Rambouliet-

Grieve not, gentle traveller, to let Madame de Rambouliet p--ss on [2001: 60, pisownia Sterne'a].

Jednym ze źródeł komizmu jest tu rozdźwięk między treścią wypowiedzi - 'Tylko wysiusiać się' - a wyborem języka, kojarzonego z elegancją i decorum [por. Goring 2001: 127].

Do antologii zamierzonej jako kompendium sentymentalizmu epizod ten wyraźnie nie pasował. Nie znajdziemy go u Galinkowskiego, bo i w Beauties [1799] rozdziałku The Rose nie ma. W przekładzie Frankowskiego pewne tuszowanie dosadności wyraziło się tym, że jest to bodaj jedyne wtrącenie nieopatrzone objaśnieniem. Czytelnik ma zrekonstruować sens na podstawie wykropkowanego bezokolicznika rosyjskiego w thumaczeniu kolejnego zdania (wzorem Sternowskiego ,p--ss”):

- Rien que pisser, - сказала мадам де Рамбуйе. -

- Не посетуй, благовоспитанный путешественник, на мадам де Рамбуйе за то, что она сошла п...... [Стерн 1940/1968: online].

Czytelnik przekładu anonimowego, pozbawiony wypowiedzi francuskiej (poddanej elipsie), musi domyślać się pominiętej frazy na podstawie kontekstu: 
Нет! отвечала она, мне должно выдти для....

Друг путешествователь! не мешай Госпоже Р. .... [Стерн 1806, vol. 1: 130].

W kontekście widocznej tu pruderii (lub cenzury, wydawca musiał bowiem uzyskać aprobatę cenzora) rozważmy przykład wyłamujący się ze strategii, która zdominowała wydanie z 1806 roku. Wbrew systematycznemu zacieraniu obecności francuszczyzny, anonimowy thumacz nadał (naddał) francuskojęzyczny tytuł jednemu z rozdziałów drugiej części. Chodzi o króciutki fragment opisujący jedną z wielu dwuznacznych sytuacji, w które nieustannie popada „czuły podróżny”. Jak zwykle pełen galanterii Yorick poprawia sprzączkę przy buciku pięknej pokojówki, a panna traci przy tym równowagę. I tu następuje nagłówek The Conquest [2001: 90], który trudno wówczas czytać inaczej niż „Podbój”. W króciutkim rozdziałku okazuje się jednak, że było to „zwycięstwo” nad sobą czy przezwyciężenie pokusy (Temptation z tytułu tego wcześniejszego rozdziałku). Anonimowy tłumacz użył jako tytułu dewizy Orderu Podwiązki: Hony soit qui mal y pense [Стерн 1806, vol. 2: 67, sic], co stanowi ciekawy przypadek równoczesnego włączenia do tekstu docelowego języka trzeciego i nawiązania do kultury oryginału. Przekładowca zapewne słusznie liczył przy tym na rozpoznawalność aluzji, gdyż brytyjski order najwyraźniej absorbował wyobraźnię Rosjan już od końca XVI wieku [Спасский 1993/2009: 27-28, 71-74] ${ }^{11}$.

\section{We Francji, czyli gdzie?}

Przyjrzyjmy się teraz przekładowej toponimii, którą wyodrębniamy w osobny punkt analizy choćby dlatego, że przy tłumaczeniu na język rosyjski spodziewać się tu należy transkrypcji lub, w przypadku miejsc bardzo znanych, zastosowania egzonimu, nie zaś transferu nazwy w źródłowym alfabecie.

Choć trasa obrana przez pastora Yoricka nie odbiega od typowej trasy Grand Tour [por. Bystydzieńska 1993: 101], Sternowska opowieść stanowi zaprzeczenie modelowej literatury podróżniczej. Zewnętrzne

\footnotetext{
11 Wkrótce po wydaniu przekładu kawalerem orderu został - jako jeden z kilku kolejnych rosyjskich monarchów - car Aleksander I, który kazał umieścić dewizę Honi soit... na gwieździe Orderu św. Andrzeja przy własnym stroju [zob. Спасский 1993/2009: tabl. XXXI, rys. 5]. Por. także wykorzystanie dewizy w XVII rozdziale części I Anny Kareniny - znacznie późniejsze, świadczące jednak o żywotności tego obcego elementu kulturowego w rozpatrywanej kulturze docelowej.
} 
szczegóły wojażu są z założenia pomijane, tematu nie stanowią realia i atrakcje odwiedzanego kraju same w sobie, lecz oddźwięk, jaki „doświadczenie obcego" wywołuje w „czułym podróżnym” [por. Goring 2001: xi]. Niemniej w utworze pojawiają się toponimy i mikrotoponimy, a częste umieszczanie ich w tytułach lub podtytułach rozdziałków pełni istotną funkcję, m.in. nadając partiom tekstu charakter zapisków czynionych w podróży. Autorefleksyjny i dygresyjny charakter narracji sprawia zresztą, że czytelnik może łatwo stracić orientację w literackiej przestrzeni. Nazwy własne wyniesione do nagłówków przypominają wtedy o miejscach akcji i nadają spójność poszczególnym większym epizodom. Warto też zaznaczyć, że mimo skąpo rozsianych w tekście informacji topograficznych, już w XIX wieku podejmowano z powodzeniem próby zlokalizowania i dookreślenia miejsc odwiedzonych przez samego Sterne'a i wzmiankowanych w powieści [np. P* [sic] 1825]. Wprawdzie normy traktowania nazw własnych w przekładzie są zmienne w czasie, a w pewnych względach na gruncie rosyjskim do dziś nie wypracowano ostatecznych rozstrzygnięć [por. Ермолович 2005: 115], tym bardziej jednak warto przyglądać się strategiom tłumaczy i badać interpretacyjne skutki ich decyzji.

W tłumaczeniu Galinkowskiego pominięcie niektórych odniesień topograficznych wiąże się ze skrótami w tekście. Sygnalizowanie jedności miejsca czy też trasy podróży traci znaczenie w przypadku wyjątków z powieści - w każdym z nich liczy się bardziej sama anegdota lub scena. Dlatego zdarza się okazjonalne usunięcie nazw miejscowości z tytułów rozdziałów: The Sword. Rennes [2001: 78] - Шnaza [1801: 122]. Mimo to wersja z 1801 roku zwykle nie budzi wątpliwości, gdzie rozgrywa się dany epizod - w przypadku Szpady Galinkowskij nie pomija nazwy „Rennes” w treści („Ренн”, [1801: 124]), w przypadku Pasztetnika, jak wspomniałam, pozostawia nazwę „Wersal” także w podtytule, itd.

Natomiast w thumaczeniu anonimowym odczuwalny jest brak nazw miejscowych. Niektóre w ogóle się nie pojawiają, gdyż nie zostały wymienione w tekście głównym, a jedynie w nagłówkach, nagłówki zaś tłumacz uprościł lub zmienił. Czytelnik wydania z 1806 roku nie dowie się, gdzie miała miejsce scenka z martwym osłem, gdyż rozdziały Nampont. The Dead Ass i The Postillion. Nampont [2001: 39, 40] noszą tytuły Мертвый осел і Почтальон [1806, vol. 1: 82, 85]. Co więcej, nagłówki zawierające elementy trzeciej kultury ustępują niekiedy miejsca tytułom o charakterze moralizatorskim, np.: 
Calais [Sterne 2001: 15] - Невестке на отместку [Стерн 1806, vol. 1: 25];

The Remise. Calais [2001: 25] - Другой воспользовался бы [Стерн 1806, vol. 1: 49].

W pierwszym wypadku rosyjski frazeologizm oznaczający ,pięknym za nadobne" odnosi się do stosowania $\mathrm{w}$ argumentacji zaprawionych uszczypliwością komplementów, w czym właściciel gospody okazuje się równie biegły jak Yorick, który tę „kazuistykę” zaczął. W drugim nieuzasadniona moralna wyższość ('Kto inny by skorzystał') została wpisana w epizod nieoczekiwanego sam na sam z piękną damą, o którym będzie jeszcze mowa niżej.

Pominięcie toponimu może rodzić ryzyko niedostatecznej spójności wewnątrztekstowej. Na przykład epizod z pasztetnikiem traci podtytuł z lokalizacją [Сахарные пирожки, 1806, vol. 2: 32], a thumacz pomija nazwę miejscowości także w rozdziale: Yorick postanawia, skoro już się tu znalazł, „посмотреть город”, obejrzeć miasto, przypuszczając, że jest niewielkie, czemu woźnica stanowczo, acz grzecznie zaprzecza. Wprawdzie cel przejażdżki został nazwany kilka stron wcześniej [ibidem: 27], ale czytelnik może odnieść wrażenie, że tym małym miastem ma być Paryż, gdy tymczasem chodzi o Wersal.

Z kolei na miejscu „Rue St Pierre” pojawia się „Петропавловская улица" [ibidem: 33], tzn. tłumacz dodaje drugiego patrona i nadaje ulicy nazwę par excellence rosyjską. Tym samym naruszona zostaje jedna z zasad przekładania onomastyki, zasada respektowania przynależności geograficznej i etniczno-kulturowej (zob. Ермолович 2005: 149-152). Pomija zaś tłumacz nazwę „Quai de Conti” w obu miejscach, gdzie powinna się pojawić [1806, vol. 2: 3, 32], przez co wydarzenia rozgrywają się $\mathrm{w}$ nieco bardziej abstrakcyjnej przestrzeni. Trudno byłoby przy tym argumentować, że atoponimia służy tu jakimś celom, jak uniwersalizacja przestrzeni miasta [por. Wołek 2006: 178-181]. Zestawienie z wcześniejszym o kilka lat przekładem uwypukla fakt, że nie wynika to $\mathrm{z}$ obowiązującej konwencji.

Tekst z 1940 roku lokalizuje akcję we Francji w takim samym stopniu, w jakim czyni to oryginał, aczkolwiek „набережная Конти” występuje tu obok „улицы Святого Петра” [Стерн 1940/1968: online, rozdz. Пирожник]. Respektowana jest też budowa nagłówków, dzięki czemu wersja dwudziestowieczna optymalnie oddaje potencjalnie istotną cechę narracji: Grażyna Bystydzieńska uważa, że wysoka frekwencja 
toponimów - wciąż tych samych - w tytułach rozdziałów służy podkreśleniu nieśpiesznego tempa podróży [1993: 101]. Trzeba także odnotować, że toponimy w przekładzie Frankowskiego przybierają formy współczesne lub znormalizowane względem idiosynkratycznych niekiedy zapisów w oryginale. Stąd „Версаль” (wobec formy „Версалия” w pozostałych analizowanych tłumaczeniach ${ }^{12}$ ), oraz „Монтрёй” - gdy wcześniejsi tłumacze transliterowali „Монтриуль” [nр. 1801: 139; 1806, vol. 2: 79], imitując zapis Sterne'a: Montriul, zamiast Montreuil.

\section{Francuzi i ich narodowy charakter}

Na tych elementach kultury trzeciej nie można jednak poprzestać. „Podróżnika sentymentalnego" przede wszystkim zajmują ludzie i to im poświęca Yorick sporo uwagi, czasami formułując też obserwacje na temat charakteru czy zachowania Francuzów w ogólności. Czyni również porównania z Anglią. Niekiedy pochwały przyprawione są ironią, niewątpliwie jednak narrator podziwia francuską dworność (którą dostrzega nawet wśród żebraków), błyskotliwość konwersacji, a także radość życia. Jak to ujmuje Thomas M. Curley, psychologiczna eksploracja podjęta przez Yoricka zmierza ku odkryciu w sobie „,kosmopolitycznej empatii wobec francuskiego charakteru narodowego" [1990: 209, tłum. własne]. I najwyraźniej się to udaje, skoro jeden z francuskich tłumaczy Sterne'a ubolewał, iż Yorick - tak francuski w wielu swoich rysach - nie jest po prostu Francuzem [cyt. za: Pickford 2007: 60]. Trzeba jednak pamiętać, że - by zaadaptować formułę Skibińskiej - owo otwarcie się na Francję dokonuje się w języku innym niż francuski [por. Skibińska 2012: 353]. Proces tłumaczenia zaś jeszcze bardziej to otwarcie komplikuje, co sprawia, że wyróżniki zaobserwowane i komentowane przez Sternowskiego narratora zasługują na przekładoznawczą analizę. Przyjrzyjmy się dwu wybranym cechom.

Rozdział Le Dimanche kończy apostrofa związana ze zwyczajowymi coniedzielnymi zabawami paryżan (tu i dalej - wytłuszczenia w cytatach moje):

12 Słownik galicyzmów w języku rosyjskim [Епишкин 2010] notuje ją jako przestarzałą, podane tam zaś cytaty pozwalają wnosić, że już w latach 20. XIX wieku zastąpiła ją forma rodzaju męskiego. 
Happy people! that once a week at least are sure to lay down all your cares together; and dance and sing and sport away the weights of grievance, which bow down the spirit of other nations to the earth [Sterne 2001: 96].

Счастливый народ! - ты по крайней мере один раз в неделю верно можешь скинуть бремя забот своих - поешь - пляшешь и забываешь свое горе, не так как другие народы! [Стерн 1801: 145]

Счастливый народ! ты по крайности хотя один раз в неделю забывать можешь свои скорби, и провождать день в радостях, сбросив с себя иго забот и печалей, удручающих все другие состояния! [Стерн 1806, vol. 2: 83]

Счастливый народ! Ведь он живет в уверенности, что, по крайней мере, раз в неделю может отрешиться от всех своих забот; может танцевать, петь и веселиться, скинув бремя горестей, которое так угнетает дух других наций [Стерн 1940/1968: online].

U Sterne'a nie jest od początku jasne, czy słowo „,people” odnosi się do miejscowej ludności, czyli Francuzów, czy też do ludzi prostych - pretekstem do tej refleksji stają się bowiem plany niedzielnej rozrywki La Fleura, służącego Yoricka. Sposób budowania porównania - „other nations”, 'inne narody' - potwierdza jednak w toku lektury pierwszą z tych możliwości. Tłumacze za punkt wyjścia biorą rzeczownik „народ”, który może oznaczać albo naród, albo - i to częściej - lud. Tok rozumowania i wybory leksykalne rozstrzygają jednak na korzyść różnych znaczeń. Galinkowskij daje w zakończeniu zdania 'inne narody/ludy', Frankowskij - jednoznacznie 'inne nacje'; w obu wypadkach sens pozostaje jak u Sterne'a. Tłumacz anonimowy nadaje wypowiedzi charakter społeczny (raczej wbrew logice): raz na tydzień jarzmo trosk zrzuca lud, w odróżnieniu od innych warstw ${ }^{13}$. Wprawdzie charakter zasygnalizowanych tu zabaw jest raczej plebejski, niemniej Yorick po prostu wzdycha z zazdrością wobec francuskiej joie de vivre. Ciekawe, że podobnego ideologicznego przesunięcia nie dokonał Frankowskij, na którym ciążył obowiązek stworzenia przekładu na miarę „realizmu socjalistycznego” [por. Будрин 2016].

13 To znaczenie słowa „состояние” notuje - już jako przestarzałe - Ушаков 1935-1940. 
Wskazówek do określenia charakteru narodowego upatruje wojażer w sprawach drobnych - co Jean Viviès [2002/2016: 63] łączy z empiryzmem obserwacji i wniosków. Z ironią otóż punktuje podróżnik skłonność Francuzów do przesady, którą dostrzega w paryskim cyruliku (zapewnia on, że lok peruki nie opadnie od wilgoci, choćby go zamoczyć całym morzem):

In honest truth [...], The French expression professes more than it performs [Sterne 2001: 48, kursywa za źródłem].

Правду сказать: Француз всегда думает больше, нежели сделать может; так по крайней мере мне кажется [Стерн 1806, vol. 1: 102].

По честной правде [...], франиузское выражение обещяает больше, чем исполняет [Стерн 1940/1968: online].

Frankowskij odtwarza wywód myślowy Yoricka, w którym diagnoza na temat hiperbolicznego wyrażenia podpiera pewną szerszą argumentację, pozostając przy tym komentarzem do jednej wypowiedzi. Jego dziewiętnastowieczny poprzednik zamienia to w uogólnienie: Francuz zawsze myśli więcej (= obiecuje więcej), niż może wykonać. Jest to sąd, który w tekście Sterne'a nie ma oparcia, a niewątpliwie współtworzy obraz Francji i jej mieszkańców przekazywany czytelnikom przekładu. Przy tym, jak się wydaje, przesunięcie to wynika nie z celowego manipulowania warstwą aksjologiczną powieści, ale z trudności ze zrozumieniem tekstu wyjściowego - zmian o takim podłożu jest w przekładzie więcej.

\section{Francuska obyczajowość}

„Sentymentalny podróżny” odnotowuje także pozycję kobiety w społeczeństwie francuskim. Zauważa, że panie mogą wykazywać się - i wykazują - przedsiębiorczością i aktywnością w różnych sferach. Zaś aktywność ta daje im obycie towarzyskie i subtelność, której - przynajmniej w sferach mieszczańskich - brak mężczyznom. Przytaczam cały passus oryginalny oraz niezbędne fragmenty tekstów rosyjskich:

The genius of a people where nothing but the monarchy is salique, having ceded this department, with sundry others, totally to the women-by a continual higgling with customers of all ranks and sizes from morning to night, like so many rough pebbles shook long together in a bag, by amicable 
collisions, they have worn down their asperities and sharp angles, and not only become round and smooth, but will receive, some of them, a polish like a brilliant-Monsieur le Mari is little better than the stone under your foot[Sterne 2001: 52].

Дух такого народа, где все[,] кроме самодержавия, неисключительно женскому полу** уступивши совершенно сию честь со многими другими одним женщинам [...]

** La Loi salique [Стерн 1801: 156].

Mr. le mari - (муженек) право несколько глаже камня, что на мостовой [ibidem: 157].

[...] Во Франции женщины управляют всем, кроме государства [Стерн 1806, vol. 1: 110].

['Monsieur le Mari...'- zdanie opuszczone]

Так как гений народа, у которого только монархия основана на салическом законе, предоставил эту отрасль, наряду с разными другими, в полновластное распоряжение женщин, [...] между тем как мосье le Mari* немногим лучше булыжника, на который вы ступаете [Стерн 1940/1968]. * Муж (франц.).

Салический закон - запрещал женщинам во Франции наследовать престол [ibidem: online, przypisy końcowe A. Frankowskiego].

Wszystkie rozpatrywane thumaczenia przekazują sens, natomiast nie wszystkie przywołują element trzeciej kultury, jakim jest odniesienie do prawa salickiego. Galinkowskij, autor najstarszego z omawianych przekładów, informuje czytelników, że kobiety nie są wyłączone z niczego poza władzą absolutną (samodzierżawiem), a w przypisie zaledwie sygnalizuje przyczynę tego jedynego wyłączenia, i to w języku francuskim. Tłumacz dwudziestowieczny postępuje odwrotnie: w tekście głównym komunikuje, że tylko monarchia podlega prawu salickiemu, reszta zaś należy do kobiet, a w przypisie objaśnia, iż prawo to odsuwało kobiety od dziedziczenia tronu Francji. W przekładzie z roku 1806 czytamy po prostu, że we Francji kobiety rządzą wszystkim oprócz państwa. Tłumacz anonimowy poza tym tuszuje niekorzystne dla mężczyzn porównanie, pomija bowiem zdanie o ,panu mężu”. Ciekawe, że i Galinkowskij, i Frankowskij pogłębiają natomiast ten kontrast: jeden poprzez zastosowanie 
protekcjonalnego zdrobnienia „муженек”, drugi - używając gminnej formy „мосье” zamiast „месье”.

Przejdźmy do innego przykładu. Yoricka interesuje Francja jako kraj galanterii i kraj tytułowych sentymentów, czyli delikatnych uczuć, no i kraj miłości. Do przekładu wkradnie się zatem dysonans, jeśli tłumacz narzuci podejście moralizatorskie. Na początku podróży, w Calais, Yorick spotyka piękną smutną damę, z którą - tak się składa - najpierw zostaje sam na sam, a potem, podczas oglądania powozów do wynajęcia, zostają wręcz zamknięci razem w karecie. Dama uznaje sytuację za zabawną: C'est bien comique - stwierdza [Sterne 2001: 26]. Yorick podchwytuje, że prawdziwie komicznie byłoby, w duchu francuskim, wykorzystać tę sytuację do natychmiastowego oświadczenia swych uczuć:

- There wants nothing, said I, to make it so, but the comick use which the gallantry of a Frenchman would put it to - to make love the first moment, and an offer of his person the second [ibidem: 26].

W przekładzie z 1806 roku Yorick przemawia jak zgorszony, i to nie tyle sytuacją, ile francuskimi obyczajami... Stwierdza, że chyba tylko we Francji śmieją się w takich okolicznościach, bo to kraj, gdzie w jednej godzinie znajomości wyznaje się miłość, a w drugiej oddaje się w posiadanie ukochanej osobie - to ostatnie sformułowanie sugeruje o wiele większą intymność niż oryginał:

Чего ж к тому недостает, сударыня? Может быть в одной только Франции смеются над такими случаями; там, где в первый час свидания открываются в любви, а во второй отдают себя во власть любимой особе [Стерн 1806, vol. 1: 51].

Porównajmy również tekst Frankowskiego:

- Чтобы получилось совсем забавно, - сказал я, - не хватает только комичного употребления, которое сделала бы из этого французская галантность; сначала объясниться в любви, а затем предложить свою особу [Стерн 1940/1968: online].

W anonimowym tłumaczeniu pominięty zostaje pozytywnie nacechowany epitet 'francuska galanteria' (zachowany u Frankowskiego). Natomiast przekształcenie syntaktyczne wprowadza ton dezaprobaty wobec miejscowych zwyczajów. Oryginał podkreśla też, że chodzi o dworność wobec kobiety - to mężczyzna, ,a Frenchman”, ofiarowuje swoją osobę. 
Konstrukcja rosyjska $\mathrm{w}$ anonimowym thumaczeniu jest inkluzywna: 'oddają się', 'oddaje się siebie' (por. wyróżnienia). W przekładzie tym inna jest zatem nie tylko ocena zachowań ukazanych tu jako typowe, ale i same te zachowania.

$\mathrm{Na}$ koniec zwróćmy uwagę na inny aspekt narodowej dworności, powracając do epizodu z kawalerem Orderu św. Ludwika, zmuszonym przez biedę do zajęcia się ulicznym handlem. Anonimowy thumacz nie zadowala się odtworzeniem wielkodusznej wypowiedzi oficera, który, choć strawił młodość w królewskiej służbie, nie spodziewa się nagrody:

The king, he said, was the most generous of princes, but his generosity could neither relieve [n]or reward every one [...] [Sterne 2001: 77].

„Король наш Государь столько же добрый, как и правосудный, продолжал он, но в силах ли наградить весь свет, и облегчить участь всех несчастных?" [Стерн 1806, vol. 2: 36].

Epitety ulegają rozbudowaniu: 'król, nasz pan', 'dobry i sprawiedliwy'; w rezultacie rycerskość i skromna godność przekształca się w dykcję wiernopoddańczą. Kiedy wiadomość o losie i postawie kawalera dociera do króla i ten obdarowuje go roczną pensją, tłumacz dopisuje zaś następujący komentarz:

Блажен народ, где Государь добродетелен! [ibidem: 37]

[dosł. 'Błogosławiony naród, który ma szlachetnego władcę!']

W planie bezpośrednim wypowiedź odnosi się do konkretnego monarchy, który nagrodził bohatera tej opowieści, i włożona jest w usta narratora. Yorick jakby zapomniał, że w pierwszym rozdziale zżymał się na króla Francji i na małoduszne prawo, droits d'aubaine, na mocy którego wszelka własność cudzoziemca zmarłego we Francji przechodzi w posiadanie Korony [Sterne 2001: 5; Стерн 1806, vol. 1: 4-5]. Z kolei przy porównaniu $\mathrm{z}$ oryginałem podwyższona emocjonalność puenty uderza w zestawieniu z ironią sformułowania Sterne'a: „he [the king] broke up his little trade by a pension of fifteen hundred livres a year" [2001: 78].

Warto zastanowić się nad historyczno-politycznymi okolicznościami powstania obu tekstów, źródłowego i docelowego, a były one nieco podobne. Sterne podróżował po Francji w latach 1762-1764, przy czym Anglia i Francja znajdowały się jeszcze w zasadzie w stanie wojny; traktat kończący wojnę siedmioletnią podpisano w 1763 roku. Z kolei w roku 
1806 stosunki rosyjsko-francuskie były raczej napięte (po bitwie pod Austerlitz, przed pokojem w Tylży). Trudno przypuszczać, by owo dopisane przez thumacza entuzjastyczne wykrzyknienie miało się odnosić do Napoleona Bonaparte. $Z$ jednej strony może ono zatem - w tak ogólnie sformułowanej postaci - być zawoalowanym hołdem dla Aleksandra I. $\mathrm{Z}$ drugiej zaś skłania do zwrócenia uwagi na pełny tytuł, jaki w tym wydaniu nadano A Sentimental Journey. A brzmi on: Путешествие Йорика по Франции или, Забавные и остроумные замечания и живописные оттенки нравов и характера франиузского народа до Революиии 'Podróż Yoricka po Francji, czyli zabawne i dowcipne obserwacje i w żywych barwach odmalowane obyczaje i charakter narodu francuskiego przed Rewolucją'. Tłumacz czy też wydawca deklaruje tu wprawdzie zainteresowanie obcością (aczkolwiek przeprowadzona wyżej analiza po części podaje w wątpliwość szczerość tej deklaracji), ale Francja, jaką chce pokazać, to Francja sprzed rewolucyjnych przemian. Niemal czterdzieści lat, jakie upłynęły od pierwszego angielskiego wydania powieści, wytwarza bezpieczny dystans i pozwala zaoferować odbiorcom (a może tylko cenzorom?) obraz nie Francji współczesnej, lecz Francji Burbonów i lojalnych poddanych.

\section{Wnioski}

Prześledzony materiał nasuwa wnioski dotyczące kilku obszarów. Po pierwsze, dwa przekłady usytuowane względem siebie synchronicznie i najnowszy, wchodzący z nimi w relację diachroniczną, pozwalają dostrzec, że traktowanie wstawek z języka trzeciego nie pozostaje, jak można by oczekiwać, w prostej zależności od ewoluującej w czasie normy translatorskiej. Tłumaczenia, których powstanie dzieli pięć lat, diametralnie różnią się strategią „,(nie)dopuszczania do głosu” trzeciego języka. Natomiast przekłady z 1801 i 1940 roku wykazują podobieństwa, jeśli chodzi o wyraźny zamiar odtworzenia elementów kultury trzeciej (językowych i onomastycznych).

Oba thumaczenia z początku XIX wieku to odczytania „prostolinijnie sentymentalne", niezauważające żywiołu parodiującego gatunek od środka - tak bowiem wtedy odbierano Sterne'a w Rosji. Antologijny charakter publikacji przygotowanej przez Jakowa Galinkowskiego mógłby sugerować projekcję czytelnika słabiej przygotowanego do odbioru wszelkich treści poza „uczuciowymi”, natomiast poszerzone wydanie 
z 1806 roku - czytelnika nieco ambitniejszego. Tymczasem jest odwrotnie: to Galinkowskij, mimo że adresuje swoje wydanie do „czułych serc”, oczekuje od odbiorcy większej otwartości na obcość i większej aktywności lekturowej, o czym świadczy m.in. zastosowanie zwrotu „la Loi salique" jako objaśnienia.

Jaki obraz Francji wyłania się ze zbadanych tłumaczeń? W wariancie Galinkowskiego jest on niepełny z uwagi na specyficzny dobór fragmentów, jednak wbrew pozorom bogatszy i bliższy oryginałowi, niż można by się spodziewać. Z kolei thumacz anonimowy z 1806 roku nie wykazuje żadnego nastawienia na elementy trzeciej kultury, co może dziwić w publikacji wydanej w drukarni uniwersyteckiej. Obserwujemy za to dydaktyzm oraz odkształcenia ideowe, wynikające często z niezrozumienia tekstu wyjściowego. $\mathrm{Z}$ nieporadnością thumacza (bo, jak pokazuje kontrast ze współczesnym mu przekładem Galinkowskiego, nie z obowiązującą konwencją) łączyć może trzeba także zaburzenia onomastyki i atoponimię. Nieobecność językowych elementów francuszczyzny rodzi ponadto podejrzenie, że mimo zapewnienia na stronie tytułowej (,перевод с подлинника”) przekład nie powstał na podstawie oryginału, lecz wywodzi się z wersji francuskiej, lub też że kolacjonowanie tekstu angielskiego, nad którym thumacz w pełni nie panował, $\mathrm{z}$ francuskim ${ }^{14}$ zaślepiło anonimowego przekładowcę na zjawiska heterojęzyczności i innokulturowości. Tłumaczenie Adriana Frankowskiego pod względem wielu parametrów już zbadanych uchodzi za lepsze od poprzednich [por. Будрин 2016: 145-146, Салиева 1992: 24]. W odniesieniu do elementów trzeciej kultury ta diagnoza się potwierdza; w przekładzie odzwierciedla się rozwój warsztatu filologicznego oraz fakt korzystania z opracowań krytycznych tekstu źródłowego - co ustalił Budrin i czego dowodzą również przypisy thumacza. W rezultacie powstaje obraz Francji najpełniejszy z analizowanych tu, zasadniczo zbieżny $\mathrm{z}$ obrazem $\mathrm{w}$ angielskim oryginale.

Warto pamiętać, że wszyscy trzej przekładowcy pracowali pod presją ideologiczną (dziewiętnastowieczni - carskiej cenzury, Frankowskij - cenzury i krytyki radzieckiej). Mimo to niekoniecznie odnajdujemy w ich tekstach rozwiązania, których te okoliczności pozwalałyby oczekiwać. Carowi Aleksandrowi I dedykowana jest antologia Galinkowskiego

14 Hipotezę tę potwierdza fakt, że przekład z 1806 roku wykazuje na poziomie tytułów rozdziałów (choć nie brzmienia tekstu!) wielką zbieżność z tłumaczeniem obejmującym tylko dwa tomy, również anonimowym, dokonanym trzy lata wcześniej z francuskiego (Чувственное путешествие Стерна во Франциию. С франиузского, 2 ч. [tłum. anonim.], Москва, Губернская типография А. Решетникова, 1803). 
[1801: strony b. pag.], ale to do wydania z 1806 roku włączono rojalistyczny okrzyk. Z kolei Frankowskij nie korzysta z okazji do „klasowego" zinterpretowania tekstu.

$\mathrm{Na}$ koniec podkreślmy to, co nasuwa się jako wniosek metodologiczny. To nie „namacalne” elementy kultury trzeciej okazują się najbardziej podatne na znaczące odkształcenia. Owszem, obcojęzyczne wstawki mogą zniknąć, ale momenty metajęzykowe narracji i dialogów ujawniają ich brak; podobnie zatarcie toponimii wytwarzające pustkę kulturową lub też udomowienie toponimii to sygnały, które wzbudzą czujność aktywnego odbiorcy. Natomiast tym, co podlega odkształceniom niewykrywalnym w lekturze niezwiązanej, jest obraz kultury trzeciej zawarty w zdaniach o charakterze sądów (Francuzi charakteryzują się określonymi cechami, we Francji postępuje się tak a tak). I jest to zagadnienie godne dalszych badań.

\section{Bibliografia}

Adams, P. G. (2014), Travel Literature and the Evolution of the Novel, University of Kentucky, [b.m.].

Beauties (1799) - The Beauties of Sterne; including many of his letters and sermons, all his pathetic tales, humorous descriptions \& most distinguished observations on life. Printed for G. Kearsley et al., London, wyd. 13.

Bednarczyk, A. (2002), Kulturowe aspekty przekładu, Śląsk, Katowice.

Bystydzieńska, G. (1993), W labiryncie prawdy. Studia o twórczości Laurence'a Sterne' $a$, Wydawnictwo UMCS, Lublin.

Curley, T. M. (1990), „Sterne's A Sentimental Journey and the Tradition of Travel Literature", [w:] John McVeagh, red. English Literature and the Wider World, vol. 1, All Before Them: Attitudes to Abroad in English Literature 1660-1780, Ashfield, London, 203-216.

Drabble, M. (red.) (2000), The Oxford Companion to English Literature, Oxford UP, Oxford.

Goring, P. (2001), „Introduction”, „Note on the text”, „Notes”, [w:] Laurence Sterne, A Sentimental Journey, Penguin Books, London, xi-xxxvi, 119-135.

Kaźmierczak, M. (2016), „Na peryferiach teorii - trzeci język w przekładzie”, Między Oryginatem a Przekładem. 1(31): 61-89.

P*. (1825), „Sterne at Paris and Versailles”, The London Magazine and Review. New Series. 1(3): 387-394. 
Pickford, S. (2007), „Between Version and Traduction: Sterne's Sentimental Journey in Mid-Nineteenth-Century France", Translation and Literature. 1(16): 53-65, https://doi.org/10.3366/tal.2007.0009.

Skibińska, E. (2008), Kuchnia ttumacza. Studia o polsko-francuskich relacjach przekładowych, Universitas, Kraków.

Skibińska, E. (2012), „Tłumacz wobec powieściowej heterojęzyczności”, [w:] Maria Piotrowska et al., red. Kompetencje thumacza: tom dedykowany Profesor dr hab. Elżbiecie Tabakowskiej, Krakowskie Towarzystwo Popularyzowania Wiedzy o Komunikacji Językowej „Tertium”, Kraków, 351-369.

Sterne, L. (2001), A Sentimental Journey through France and Italy by Mr. Yorick, (1768), wstęp i red. Paul Goring, Penguin Books, London 2001.

Urbanek, D. (2002), Elementy trzeciej kultury w procesie przektadu, [w:] Roman Lewicki, red. Przekład-język - kultura, Wydawnictwo UMCS, Lublin, 61-70.

Viviès, J. (2002/2016), English Travel Narratives in the Eighteenth Century. Exploring Genre (thum. Claire Davison), Routledge, London-New York, https://doi.org/10.4324/9781315256429.

Wołek, K. (2006), „Obecność trzeciej kultury w przekładzie”, [w:] Maria Filipowicz-Rudek, Jadwiga Konieczna-Twardzikowa, red., Między oryginatem a przekładem. 11: 171-182.

Будрин, П. (2016), „«Сентиментальное путешествие» Стерна в советских переводах", [w:] Текстология и историко-литературный прочесс. Сборник статей. 4, МГУ, Москва: 141-158.

Епишкин, Н. И. (2010), Исторический словарь галлицизмов русского языка, Словарное издательство ЭТС, Москва.

Ермолович, Д. И. (2005), Имена собственные: теория и практика межъязыковой передачи, Р. Валент, Москва.

Салиева, Л. К. (1992), Метод историко-стилистического анализа переводных текстов (на материале переводов на русский язык романа Л. Стерна «Сентиментальное путешествие»), [autoreferat rozprawy doktorskiej], МГУ, Москва.

Спасский, И. Г. (1993/2009), Иностранные и русские ордена до 1917 года, ilustr. В. Трофимов, Вече, С-Петербург.

Стерн, Л. (1801), Красоты Стерна, или собрание лучших его патетических повестей и отличнейших замечаний на жизнь, для чувствительных сердеu, с англ., (tłum. Яков Галинковский), Сенатская типография, Москва. 
Стерн, Л. (1806), Путешествие Йорика по Франции, 4 ч., [thum. anon.], Университетская типография, Москва.

Стерн, Л. (1940/1968), Сентиментальное путешествие по Франции и Италии, (tłum. Адриан Франковский), Художественная литература, Москва 1968, [online] http://www.lib.ru/INOOLD/STERN/stern_puteshestvie.txt, 1.10.2018.

Ушаков, Д. Н. (1935-1940), Толковый словарь русского языка, 4 t., red. Д. Ушаков, DISC-0507, ИДДК, Москва 2004.

Budrin, P. (2016), „«Sientimientalnoje putieszestwije» Stierna w sowietskich pieriewodach", [w:] Tiekstołogija i istoriko-litieraturnyj process. Sbornik statiej. 4, MGU, Moskwa: 141-158.

Jepiszkin, N. I. (2010), Istoriczeskij słowar' gallicyzmow russkogo jazyka, Słowarnoje izdatielstwo ETS, Moskwa.

Jermołowicz, D. I. (2005), Imiena sobstwiennyje: tieorija i praktika mieżjazykowoj pieriedaczi, R. Walent, Moskwa.

Salijewa, L. K. (1992), Mietod istoriko-stilisticzeskogo analiza pieriewodnych tiekstow (na matieriale pieriewodow na russkij jazyk romana . Stierna «Sientimientalnoje putieszestwije»), [autoreferat rozprawy doktorskiej], MGU, Moskwa.

Spasskij, I. G. (1993/2009), Inostrannyje i russkije ordiena do 1917 goda, ilustr. W. Trofimow, Wiecze, S-Pietierburg.

Stiern, Ł. (1801), Krasoty Stierna, ili sobranije tuczszych jego patieticzeskich powiestiej i otliczniejszych zamieczanij na żyzn', dla czuwstwitielnych sierdiec, $s$ angl., (tłum. Jakow Galinkowskij), Sienatskaja tipografija, Moskwa.

Stiern, Ł. (1806), Putieszestwije Jorika po Francyi, 4 cz., [thum. anon.], Uniwiersitietskaja tipografija, Moskwa.

Stiern, Ł. (1940/1968), Sientimientalnoje putieszestwije po Francyi i Italii, (thum. Adrian Frankowskij), 1968, [online] http://www.lib.ru/INOOLD/STERN/ stern_puteshestvie.txt, 1.10.2018.

Uszakow, D.N. (1935-1940), Tołkowyj słowar'russkogo jazyka, 4 t., red. D. Uszakow, DISC-0507, IDDK, Moskwa.

\section{STRESZCZENIE}

Artykuł podejmuje wątki związane z historią i ewolucją praktyk przekładowych w kontekście obrazu trzeciej kultury. Ma na celu zarysowanie tendencji w językowym i konceptualnym prezentowaniu obrazu Francji 
w rosyjskich przekładach Podróży sentymentalnej Laurence'a Sterne'a powstałych w XIX i XX wieku. Autorka rozpatruje wstawki obcojęzyczne i toponimię, ale także wizerunek Francuzów, ich charakteru i obyczajowości, wyrażony w passusach nienacechowanych heterojęzycznością. Argumentuje, że na obraz trzeciej kultury znaczny wpływ ma właśnie przekład zdań o bezpośrednim charakterze sądów.

Słowa kluczowe: trzecia kultura, heterojęzyczność, Francja, Laurence Sterne, aksjologia

\section{Abstract}

The Image of France in Selected Russian Translations of Sterne's A Sentimental Journey

The paper discusses issues connected with the history and evolution of translation practices with respect to the representation of a third culture. The aim is to outline the tendencies in linguistic and cultural profiling of the image of France in Russian 19th- and 20th-century renditions of Laurence Sterne's A Sentimental Journey. The author surveys third-language intrusions and toponyms, as well as the image of the French, their national character and social behaviour in passages not marked by heterolingualism. She claims that precisely the passages pronouncing judgements or opinions are of great importance in forming the image of a third culture in translated texts.

Keywords: third culture, heterolingualism, France, Laurence Sterne, axiology 